The climate of the southern limit isMean (January). Mean (July). $72^{\circ} \cdot 5 \mathrm{~F}$. $57^{\circ} \cdot 5 \mathrm{~F}$.

Mean (Annual). $65^{\circ} \circ \mathrm{OF}$.

The mean of both beingMean (January). Mean (July). $77^{\circ} \cdot 25 \mathrm{~F}$. $\quad 64^{\circ} \cdot 25 \mathrm{~F}$.

Mean (Annual). $70^{\circ} \cdot 75 \mathrm{~F}$

The present mean annual temperature of Bournemouth is only $50^{\circ} .4 \mathrm{~F}$., which is $20^{\circ} \cdot 35 \mathrm{~F}$. below its mean annual temperature in the Eocene period.

I want to know how Lyell and his followers propose to give to Bournemouth, from present existing forces and causes, this additional $20^{\circ} \mathrm{F}$. of heat. If geologists really wish to earn the respect of their fellow-workers in more exact branches of knowledge, they must condescend to consider quantitative as well as qualitative questions, and enter into numerical details. To enable them to do so I lay down the two following statements :-

I. Of all places now existing on the same parallel of latitude as Bournemouth the highest mean temperature is in $20^{\circ} \mathrm{W}$. long. (in the Atlantic), where the temperature is $53^{\circ} . \mathbf{I}$ F., or only $2^{\circ} \cdot 7 \mathrm{~F}$. above that of Bournemouth.

Of all places on the same parallel the lowest mean temperature is found at $80^{\circ} \mathrm{W}$. long. (on the borders of Labrador and Canada), where it is $29^{\circ} \cdot 3 \mathrm{~F}$., which is $21^{\circ} \cdot 1 \mathrm{~F}$. below that of Bournemouth, and $2^{\circ} .7 \mathrm{~F}$. below the freezing point of water.

Existing forces and circumstances might therefore benefit Bournemouth to the extent of $2^{\circ} \cdot 7 \mathrm{~F}$. degrees, or might injure it to the extent of $2 \mathrm{I}^{\circ} \mathrm{I} \mathrm{F}$.; but how is Bournemouth to gain the $20^{\circ}$ of heat necessary for the flourishing of the Araucaria Cunninghami on its Eocene sea-shore swamps, if existing causes only were at work?

2. The place in the northern hemisphere which is now most closely allied in climate to Moreton Bay, or to Bournemouth in Eocene times, is the central part of the Gulf of California, in Western Sub-tropical America.

Again, I ask geologists of the uniformitarian school to show me how they propose to convert the climate of Bournemouth into the present climate of the Gulf of California or that of Moreton Bay by mere transposition of land and water, without shifting the position of the earth's axis, which is an inadmissible hypothesis?

Trinity College, Dublin, September 25, I880

\section{The Naini Tal Landslip}

FOR the purpose of making a thorough inquiry into the details of the causes that led to the above lamentable disaster an able geologist would undoubtedly be required, as was suggested in your leader last week. I think, however, that to any one who, like myself, has resided even but temporarily at. Naini Tal, the main cause of the recent slip must be sufficiently obvious without the aid of the geologist.

From the account of the particular buildings overwhelmed it is plain that the slip took place close to where an almost equally bad one occurred some years ago (in the winter of I865, I believe), viz., just above the Victoria Hotel, on the shoulder uniting the two peaks of Cheena and Lyria Kauta.

The foot of this shoulder forms the northern border of the Tal, or lake, for which the station is justly famed; the strata composing it, as far as I can remember, dip with the slope of the hill southwards towards the lake. Moreover, it faces the direction from which the rain mostly comes. The conditions for the production of a landslip in the direction of the lake are thus amply fulfilled,

Though landslips are not at all infrequent from this hill (one occurred near Cheena. when I was there, killing two natives), it is from its sunny aspect and comparatively gentle slope decidedly the favourite, the station being mainly built on its slopes or at its foot.

On the hill which forms the southern border of the lake the dip of the strata is in the opposite direction to the slope of the hill. It is consequently much freer from landslips, and much safer than the former, as only a few chips at most could be detached from it on the side facing the lake, by the action of rain. The nearly constant gloom however in which, from its northern aspect and its steepness combined, it is necessarily shrouded, as well as the lack of building area, naturally tends to limit its population. This hill again on its southern side, which faces the plains, repeats the same phenomena as the shoulder before mentioned; an enormous portion of it having become detached towards the plains, and called pre-eminently "The Landslip."

When staying in the Victoria Hotel in May and June, 1877 I always felt it would take very little to bring the whole hill, and especially Government House, which appeared almost vertically above us, down on top of us. The old landslip which I mentioned as being close to the present hotel buried its predecessor, and might be thought to have furnished ample warning against choosing such a dangerous spot upon to which to rear a fresh one.

To guard against such disasters in future I would suggest that all houses in the hill-stations should, if possible, be built mainly where the strata dip in the opposite direction to the slope of the hill, and that where the strata dip in the same direction as the slope of the hill all proximity to steep slopes should be avoided, and only the gentler slopes utilised for building on.

I may add that the rainfall on the present occasion seems to have been phenomenal, if, as the Times says, it was thirty-three inches in seventy-two hours. Still, extraordinary and sudden downpours of this kind must be expected, where the summer rainfall has varied from forty inches in 1877 to 117 inches in I862.

'Tunbridge Wells, October 2

\section{E. Douglas ARCHIBALD}

\section{Branch-cutting Beetles}

IT is rather curious that the story which $\mathrm{Mr}$. Ober was told in the Carribbees (NATURE, vol. xxii, p. 216) should be generally believed in Southern Brazil also, viz., that a large beetle "seizes a small branch of a tree between its enormously long nippers, and buzzes round and round the branch till this is cut off." Only in the Antilles this cutting of branches is attributed to a huge Lamellicorn, the Dynastes hercules, and in Santa Catharina to a large Longicorn, the Macrodontia cervicornis.

Everybody here will tell you this story, but nobody, as far as I know, has ever seen the beetle at work. Branches are often cut off by some animal. On a camphor-tree in my garden six branches, from $9^{\circ} 5$ to 13.5 centim. in circumference, have been cut off; and on a Pithecolobium for some time almost every morning a fresh branch had fallen down, some being even much thicker than those of the camphor-tree. The cutting is always in a plane perpendicular to the axis of the branch, as it would be were it made by a rotating beetle; but in this case an annular incision of equal depth all round the branch would be produced, and this I have never seen. On the contrary, the incision, which causes the branch to break off, consists of two parts, occupying the lower and the upper face of the brancb, meeting on one or on either side of it, and being separated by a wedge-shaped interval, which is broken by the weight of the branch, and is narrower or broader according to its toughness.

Once-many years ago-I came to the Pithecolobium tree early in the morning, when a branch was just falling down, and with it came down the animal by which it had been amputated. It was a Longicorn beetle, the well-named Oncideres amputator, Fabr, I have since seen specimens of some other species of the same genus, which had been caught by others in the act of cutting branches. It is almost unnecessary to add that they do so by gnawing, and not by whirling round the branches.

Blumenau, Santa Catharina, Brazil, $\quad$ FrITZ MülLER

$$
\text { August I3 }
$$

\section{The Tay Bridge Storm}

IN NATURE, vol. xxi. p. 468, Mr. Ley asks, relative to my letter on the Tay Bridge storm, which appeared in NATURE, vol. xxi. p. 443 , on what evidence I state "that when the velocity of the cyclone centre is very great, the strength of the wind for any gradients is increased, or at all events becomes more squally and gusty."

I much regret the circumstances which have prevented my replying to him sooner, but may now state shortly the three principal pieces of evidence which led me to that conclusion:-

1. My own observation in a large number of cyclones where the velocity of translation was very great, there has been a quality of gustiness or squalliness and intensity generally greater than is usual for the observed gradients.

2. Ever since the barometer was invented it has been known that a rapid fall of the mercury indicates worse weather than a slow one. Now we know that the rate at which this fall takes place at any station depends:-(I) On the steepness of the 